\title{
A prospective study of maternal outcome in antepartum haemorrhage in tertiary care center in northern India
}

\author{
Shaveta Jain ${ }^{1}$, Nitin Jain ${ }^{2}$, Pushpa Dahiya ${ }^{1}$, Seema Rohilla ${ }^{2}$, Roopa Malik ${ }^{1}$ \\ ${ }^{1}$ Department of Obsterics and Gynecology, Pt. B. D Sharma, PGIMS, Rohtak, Haryana, India \\ ${ }^{2}$ Department of Radiology, Pt. B.D Sharma, PGIMS, Rohtak. Haryana, India
}

Received: 30 November 2015

Accepted: 12 December 2015

*Correspondence:

Dr. Nitin Jain,

E-mail: logindrnitin@gmail.com

Copyright: (C) the author(s), publisher and licensee Medip Academy. This is an open-access article distributed under the terms of the Creative Commons Attribution Non-Commercial License, which permits unrestricted non-commercial use, distribution, and reproduction in any medium, provided the original work is properly cited.

\begin{abstract}
Background: Antepartum hemorrhage (APH) is a grave obstetrical emergency. It is leading cause of maternal death. Aim of the present study was to see maternal outcome patient with APH.

Methods: It was a prospective study carried out over a period of one year on 100 women admitted with the diagnosis of APH at Pt. B.D Sharma medical college, Rohtak, Haryana, India, a tertiary care center. 100 patients with antenatal hemorrhage were studied prospectively. History was taken regarding age, hemoglobin status, blood unit given, ultrasound done to note type of placenta, distance of placenta from Os noted, third stage and delayed complication recorded.

Results: $40.7 \%$ patients of placenta previa had immediate LSCS. $44.4 \%$ patients of placenta previa delayed LSCS was done after expectant management. $61.76 \%$ of patients of abruptio placentae had immediate vaginal delivery. $16 \%$ had atonic postpartum haemorrhage as third stage complication. One patient lynch sutures were applied. In 2 cases bilateral internal iliac artery ligation was done. In 3 cases bilateral uterine artery ligation done to control $\mathrm{PPH}$. $71 \%$ patients of APH had postpartum anemia as delayed complication.

Conclusions: The single most important factor in reducing maternal mortality has been the increase use of caesarean delivery in cases of abruptio placentae. Anemia is the most common cause of maternal morbidity (80\%) associated with APH in the present study.
\end{abstract}

Keywords: Antepartum hemorrhage, Maternal mortality

\section{INTRODUCTION}

Vaginal bleeding at any stage of pregnancy constitutes a significant concern to the patients and her doctor. Antepartum haemorrhage is still a grave obstetric emergency contributing to a significant amount of maternal morbidity and mortality in India. ${ }^{1}$

Depending on the definition used, antepartum haemorrhage complicated $2-5 \%$ of all pregnancies. ${ }_{6}^{2-5}$ Placenta previa complicate 0.33 percent to 0.55 percent of all pregnancies and incidence of placental abruption incidence is approximately 0.5 to 1 percent.
Though maternal mortality due to antepartum haemorrhage has significantly dropped in developed countries with the introduction of improved medical facilities, in developing countries, it most important cause of maternal mortility and morbidity.

We have done prospective study on patient with antepartum haemorraghe classified them in different group and see the maternal morbidity and mortality in each group.

Very few prospective study have been done on maternal mortality and morbidity, most are retrospective study. 


\section{METHODS}

The present study was conducted in the Department of Obstetrics and Gynaecology, Pt. B.D. Sharma PGIMS, Rohtak in 2011-12. 100 patients who were admitted with complaints of bleeding per vaginum after 28 weeks of gestation were included in the study. They were divided according to their diagnosis, as placenta previa, abruptio placentae and unclassified haemorrhage.

During our study period (2011-12) there were 4100 deliveries. Number of cases with antepartum haemorrhage were noted and the incidence of antepartum haemorrhage was calculated. All patients were admitted to hospital irrespective of gestational age, till delivery. At the time of admission a detailed history regarding onset, character, amount, episodes of bleeding, any predisposing factor or associated conditions like history of trauma, hypertension, preeclampsia, jaundice, nephritis, bleeding diathesis, previous history of caesarean section and curettage were recorded.

A general physical examination was carried out, vitals were recorded. Degree of anemia and signs of pregnancy induced hypertension were noted.

An abdominal examination was done, height of uterus in relation of period of gestation, abdominal contour, tone of uterus, any area of tenderness, presentation and foetal heart sound was noted down.

Ultrasonography was done for estimation of gestational age, placental localization, amount of liquor, evidence of retroplacental clot, to rule out any gross congenital malformation in baby. They were divided according to their diagnosis, as placenta previa, abruptio placentae and unclassified haemorrhage.

Vulval inspection was done to assess the amount of blood loss. Per speculum examination was done after 48 hours of stoppage of bleeding to look for any other local cause of bleeding. Per vaginal examination and termination of pregnancy were considered in cases of abruptio placenta. According to grade of placenta previa, time and mode of delivery was decided.

\section{RESULTS}

In the present study, out of 100 cases of antepartum haemorrhage 54 had placenta previa, 34 abruptio placenta and 12 patients were of unclassified haemorrhage. The incidence of placenta previa, abruptio placental and unclassified haemorrhage was $1.31 \%, 0.82 \%$ and $0.29 \%$ respectively. The overall incidence of antepartum haemorrhage was $2.43 \%$.

Table 1: Incidence of Antepartum haemorrhage.

\begin{tabular}{|llll|}
\hline $\begin{array}{l}\text { Type of } \\
\text { antepartum } \\
\text { haemorrhage }\end{array}$ & $\begin{array}{l}\text { Number } \\
\text { of } \\
\text { cases }\end{array}$ & $\begin{array}{l}\text { Percent } \\
\text { age }\end{array}$ & $\begin{array}{l}\text { Incidence } \\
(\%)\end{array}$ \\
\hline Placenta previa & 54 & 54 & 1.31 \\
\hline $\begin{array}{l}\text { Abruptio } \\
\text { placentae }\end{array}$ & 34 & 34 & 0.82 \\
\hline $\begin{array}{l}\text { Unclassified } \\
\text { haemorrhage }\end{array}$ & 12 & 12 & 0.29 \\
\hline Total & 100 & 100 & 2.43 \\
\hline
\end{tabular}

Table 2: Type of placenta previa and mode of delivery.

\begin{tabular}{|c|c|c|c|c|c|c|}
\hline \multirow{2}{*}{$\begin{array}{l}\text { Type of } \\
\text { placenta } \\
\text { previa }\end{array}$} & \multicolumn{2}{|c|}{$\begin{array}{l}\text { Total } \\
\text { number of } \\
\text { cases }\end{array}$} & \multicolumn{2}{|c|}{$\begin{array}{l}\text { Vaginal } \\
\text { delivery }\end{array}$} & \multicolumn{2}{|c|}{$\begin{array}{l}\text { Caesarean } \\
\text { delivery }\end{array}$} \\
\hline & No. & $\%$ age & No. & \%age & No. & $\%$ age \\
\hline I & 4 & 7.4 & 3 & 75 & 1 & 25 \\
\hline II & 18 & 33.3 & 5 & 27.7 & 13 & 72.2 \\
\hline III & 10 & 18.5 & 2 & 20 & 8 & 80 \\
\hline IV & 22 & 40.7 & 0 & 0 & 22 & 100 \\
\hline Total & 54 & & 10 & & 44 & \\
\hline
\end{tabular}

Table 3: Incidence according to grades of abruptio placentae.

\begin{tabular}{|lllllllll|} 
Grade & \multicolumn{2}{l}{$\begin{array}{l}\text { Total number of } \\
\text { cases }\end{array}$} & \multicolumn{2}{l}{$\begin{array}{l}\text { Number with } \\
\text { toxemia }\end{array}$} & $\begin{array}{l}\text { Number with } \\
\text { coagulation defect }\end{array}$ & Number with renal failure \\
\hline No. & \%age & No. & \%age & No. & Nage & Noage \\
\hline I & 10 & 29.5 & 2 & 20 & - & - & - & - \\
\hline II & 14 & 41.0 & 5 & 35.7 & - & - & - & - \\
\hline III & 10 & 29.5 & 3 & 30 & 3 & 30 & 2 & 20 \\
\hline Total & 34 & & 10 & 29.4 & 3 & 8.8 & 2 & 5.8 \\
\hline
\end{tabular}


Table 4: Number of blood units used in antepartum haemorrhage cases.

\begin{tabular}{|c|c|c|c|c|c|c|c|c|}
\hline \multirow[t]{2}{*}{$\begin{array}{l}\text { Type of } \\
\text { haemorrhage }\end{array}$} & \multicolumn{2}{|c|}{ None } & \multicolumn{2}{|c|}{ One unit } & \multicolumn{2}{|c|}{ Two units } & \multicolumn{2}{|c|}{$\begin{array}{l}\text { More than two } \\
\text { antepartum units }\end{array}$} \\
\hline & No. & \%age & No. & \%age & No. & $\%$ age & No. & \%age \\
\hline Placenta previa & 7 & 13 & 8 & 14.8 & 24 & 44.4 & 15 & 27.7 \\
\hline Abruptio placentae & 10 & 29.4 & 10 & 29.4 & 9 & 26.4 & 5 & 14.7 \\
\hline Unclassified haemorrhage & 8 & 66.6 & 3 & 25 & 1 & 8.3 & - & - \\
\hline Total & 25 & & 21 & & 34 & & 20 & \\
\hline
\end{tabular}

Table 5: Distance of placenta from cervical OS under USG in patients of placenta previa and mode of delivery.

\begin{tabular}{|c|c|c|c|c|c|}
\hline & \multirow{2}{*}{$\begin{array}{l}\text { Number } \\
\text { of cases }\end{array}$} & \multicolumn{2}{|c|}{ Caesarean delivery } & \multicolumn{2}{|c|}{ Vaginal delivery } \\
\hline & & No. & $\%$ age & No. & $\%$ age \\
\hline $0-2 \mathrm{~cm}$ & 40 & 38 & 95 & 2 & 5 \\
\hline$>2 \mathrm{~cm}$ & 14 & 5 & 35.7 & 9 & 64.2 \\
\hline
\end{tabular}

Table 6: Analysis of mode of treatment given to the patients and the perinatal outcome in antepartum haemorrhage.

\begin{tabular}{|c|c|c|c|c|c|c|}
\hline \multirow{2}{*}{ Mode of treatment } & \multicolumn{2}{|c|}{ Placenta previa } & \multicolumn{2}{|c|}{ Abruptio placentae } & \multicolumn{2}{|c|}{ Unclassified haemorrhage } \\
\hline & No. & \%age & No. & $\%$ age & No. & $\%$ age \\
\hline Conservative followed by LSCS & 22 & 44.4 & - & - & - & - \\
\hline $\begin{array}{l}\text { Conservative followed by vaginal } \\
\text { delivery }\end{array}$ & 6 & 11.1 & - & - & - & - \\
\hline Immediate LSCS & 22 & 40.7 & 13 & 24 & 4 & 33.3 \\
\hline Immediate vaginal delivery & 4 & 7.4 & 21 & 61.7 & 8 & 66.6 \\
\hline Total & 54 & & 34 & & 12 & \\
\hline
\end{tabular}

Table 7: Incidence of third stage complications.

\begin{tabular}{|c|c|c|c|c|c|c|c|}
\hline \multirow[t]{2}{*}{ Complications } & \multirow{2}{*}{$\begin{array}{l}\text { No. of } \\
\text { patients }\end{array}$} & \multicolumn{2}{|c|}{$\begin{array}{l}\text { Placenta } \\
\text { previa }\end{array}$} & \multicolumn{2}{|c|}{ Abruptio placentae } & \multicolumn{2}{|c|}{ Unclassified haemorrhage } \\
\hline & & No. & \%age & No. & $\%$ age & No. & $\%$ age \\
\hline Atonic postpartum haemorrhage & 16 & 9 & 16.6 & 6 & 17.6 & 1 & 8.3 \\
\hline Coagulation failure & 3 & - & - & 3 & 8.8 & - & - \\
\hline Haemorrhagic shock & 6 & 3 & 5.5 & 3 & 8.8 & - & - \\
\hline Scar dehiscence & 4 & 2 & 3.7 & 1 & 2.9 & 1 & 8.3 \\
\hline Couvelaire uterus & 3 & - & - & 3 & 8.8 & - & - \\
\hline Vaginal haematoma & 2 & - & - & 2 & 5.8 & - & - \\
\hline Retained placenta & 3 & 2 & 3.7 & 1 & 2.9 & 1 & 8.3 \\
\hline Renal failure & 2 & - & - & 2 & 5.8 & - & - \\
\hline Placenta Accreta & 2 & 2 & 3.7 & - & - & - & - \\
\hline $\mathrm{B} / \mathrm{L}$ uterine artery & 3 & 3 & 5.5 & - & - & - & - \\
\hline \multicolumn{8}{|l|}{ ligation } \\
\hline $\mathrm{B} / \mathrm{L}$ internal illiac artery & 2 & 2 & 3.7 & - & - & - & - \\
\hline \multicolumn{8}{|l|}{ ligation } \\
\hline B-lynch sutures & 1 & 1 & 1.8 & - & - & - & - \\
\hline Hysterectomy & 2 & 2 & 3.7 & - & - & - & - \\
\hline Maternal mortality & 2 & - & - & 2 & 5.8 & - & - \\
\hline
\end{tabular}


All cases of type IV placenta previa delivered by caesarean section. Even in $80 \%$ of type III placenta previa caesarean section had to be done, while $75 \%$ cases of type I placenta previa delivered vaginally. In two cases of type III placenta previa after admission placental migration occurred and these patients delivered vaginally.

$41 \%$ of patients having abruptio placentae were in grade II and in 10 patients abruptio placentae was seen in patients of toxemia of pregnancy. 3 patients of grade III abruptio placentae had coagulation defect and 2 patients of grade III abruptio placentae had acute renal failure

$87 \%$ patients of placenta previa received blood transfusion. $27.7 \%$ patients of placenta previa required more than 2 units blood transfusion. $70.6 \%$ having abruptio placentae required blood transfusion.

95\% cases of placenta previa whose placenta was less than $2 \mathrm{~cm}$ from os under USG delivered by LSCS.

40.7\% patients of placenta previa had immediate LSCS. $44.4 \%$ patients of placenta previa were kept on conservative management and later LSCS was done after expectant management. $61.76 \%$ of patients of abruptio placentae had immediate vaginal delivery.

Out of 100 cases of antepartum haemorrhage, $16 \%$ had atonic postpartum haemorrhage. Out of these in two cases subtotal hysterectomy had to done, to control postpartum haemorrhage. In one patient lynch sutures were applied. In 2 cases bilateral internal iliac artery ligation was done. In 3 cases bilateral uterine artery ligation done to control PPH. One patient died because of profuse haemorrhage. One patient of abruptio placenta admitted in haemorrhagic shock not revived.

Table 8: Incidence of delayed complications in antepartum haemorrhage cases.

\begin{tabular}{|c|c|c|c|c|c|c|}
\hline \multirow{2}{*}{$\begin{array}{l}\text { Complicat } \\
\text { ions }\end{array}$} & \multicolumn{2}{|c|}{$\begin{array}{l}\text { Placenta } \\
\text { previa }\end{array}$} & \multicolumn{2}{|c|}{$\begin{array}{l}\text { Abruptio } \\
\text { placentae }\end{array}$} & \multicolumn{2}{|c|}{$\begin{array}{l}\text { Unclassified } \\
\text { haemorrha- } \\
\text { ge }\end{array}$} \\
\hline & No. & $\begin{array}{l}\% \\
\text { age }\end{array}$ & No. & $\begin{array}{l}\% \\
\text { age }\end{array}$ & No. & $\begin{array}{l}\% \\
\text { age }\end{array}$ \\
\hline $\begin{array}{l}\text { Febrile } \\
\text { morbidity }\end{array}$ & 6 & 11.1 & 6 & 17.6 & 1 & 8.3 \\
\hline $\begin{array}{l}\text { Puerperal } \\
\text { sepsis }\end{array}$ & 4 & 7.4 & 2 & 5.8 & 1 & 8.3 \\
\hline $\begin{array}{l}\text { Stitch } \\
\text { sepsis }\end{array}$ & 3 & 5.5 & 3 & 8.8 & 1 & 8.3 \\
\hline $\begin{array}{l}\text { Urinary } \\
\text { tract } \\
\text { infection }\end{array}$ & 5 & 9.2 & 3 & 8.8 & 0 & 0 \\
\hline $\begin{array}{l}\text { Postpartum } \\
\text { anemia }\end{array}$ & 36 & 66.6 & 30 & 88.2 & 5 & 41.6 \\
\hline $\begin{array}{l}\text { Renal } \\
\text { failure }\end{array}$ & - & & 1 & 2.9 & - & - \\
\hline
\end{tabular}

Seventy one patients of antepartum haemorrhage had postpartum anemia. One patient had renal failure as delayed complication.

\section{DISCUSSION}

Antepartum haemorrhage is an important cause of maternal morbidity and mortality.

In the present study incidence of antepartum haemorrhage patient was $2.43 \%$. Incidence of placenta previa, abruptio placentae and unclassified haemorrhage was $1.31 \% \quad(n-54), \quad 0.82 \% \quad(n=34), 0.29 \% \quad(n=12)$ respectively[Table-1]. This is similar to the study of Arora et al in which incidence of antepartum haemorrhage was $2.53 \%$. Placenta previa - $1.17 \%$, abruptio $0.63 \%$ and unclassified $0.52 \%$.

In our study $29.4 \%$ of abruptio placentae were associated with toxemia of pregnancy and most of these patients had higher grade (Grade II and III) placental abruption [Table-3]. This is comparable with study of Abdella et al who showed $26.8 \%$ incidence of toxemia of pregnancy with abruptio placentae. ${ }^{9}$

Our study showed no case of coagulopathy or renal failure in grade I and II abruptio placentae while cases in Grade III, there were three cases of coagulation failure $(33.33 \%)$ and 2 cases of renal failure (20\%) [Table-3].

This is similar to the study of Menon et al who reported $24.8 \%$ incidence of coagulation failure in grade III abruptio placentae in 125 cases. $^{10}$

In the present study $87.2 \%$ patients of placenta previa and $70.6 \%$ patients of abruptio placenta required blood transfusion [Table-4]. Brenner et al reported 36\% incidence of blood transfusion in placenta previa ${ }^{11}$ and William reported blood transfusion in $52.4 \%$ of 189 cases of abruptio placentae reported. ${ }^{12}$ The higher incidence of blood transfusion in our study is due to high prevalence of anemia in our patients.

Incidence of caesarean section in our study declined from $95 \%$ to $35.7 \%$ if placental edge was greater than $2 \mathrm{~cm}$ away from os [Table-5]. Bhide et al also reported caesarean section in $90 \%$ case when placental edge internal os distance was 0.1 to $2 \mathrm{~cm}$ falling to $37 \%$ when measures over $2 \mathrm{~cm} .^{13}$

In the present study out of 54 cases of placenta previa 9 (16.6\%) had atonic postpartum haemorrhage, $3(5.5 \%)$ had haemorrhagic shock, $2(3.7 \%)$ had scar dehiscence and 2 had retained placenta $(3.7 \%), 2(3.7 \%)$ had placenta accreta. Emergency hysterectomy was done in 2 patients (3.7\%), one for placenta accreta and another for atonic postpartum haemorrhage [Table-7]. Crane et al also reported similar complications placenta previa like postpartum haemorrhage (20\%), haemorrhagic shock (7\%), scar dehiscence 5\% and placenta accreta 5\% in 
their study. ${ }^{14}$

Surgical management of postpartum haemorrhage was done in 5 cases. In 3 cases bilateral uterine artery ligation and another 2 cases required bilateral internal iliac artery ligation to control postpartum haemorrhage. In one patient additional B-lynch sutures were applied to control postpartum haemorrhage [Table-7]. The use of Bilateral uterine artery ligation, bilateral internal iliac artery ligation and B lynch sutures to control postpartum haemorrhage are also reported in various studies. ${ }^{15-17}$

Postpartum anemia is most common delayed complication in our study, Seventy one patients of antepartum haemorrhage had postpartum anemia [Table$8]$.

The incidence of maternal mortality was $2 \%$ in antepartum haemorrhage in our study which was consistent with study of Motwani et al who reported similar incidence. ${ }^{18} 6 \%$ maternal mortility was seen in abruptio placentae. It is similar to the published literature. ${ }^{19}$ No maternal mortality was observed in cases of placenta previa and unclassified haemorrhage. No mortality in patients of placenta previa in our series was due to early diagnosis by ultrasound, inpatient and expectant management, repeated blood transfusion and liberal use of caesarean sect.

\section{CONCLUSIONS}

Analyzing the incidence of antepartum haemorrhage, we observed that it is still a significant obstetric problem in our setup. Though maternal mortality has reduced with modern management of antepartum haemorrhage, perinatal mortality still remains high.

The single most important factor in reducing maternal mortality has been the increase use of caesarean delivery in cases of abruptio placentae. Vaginal delivery is appropriate in selected cases of placenta previa.

The present study reveals that educating the pregnant mother about the importance of antenatal care and easy accessibility to quality antenatal services would go a long way in bringing down the maternal morbidity and mortality associated with antepartum haemorrhage, ultrasonography to decide about the time of interventions and the more liberal use of caesarean section in well equipped hospitals with availability of blood transfusion services, will help to lower the maternal morbidity and mortality.

\section{Funding: No funding sources}

Conflict of interest: None declared

Ethical approval: The study was approved by the Institutional Ethics Committee

\section{REFERENCES}

1. Arora R, Devi U, Majumdar K. Perinatal morbidity and mortality in antepartum haemorrhage. J Obstet Gynae India. 2001;51(3):102-4.

2. Cunningham FG, Gant NF, Leveno KJ, Gistrap III LC, Hauth JC, Wenstrom KD. Obstetrical hemorrhage: Williams Obstetrics. 21st ed. New York, McGraw Hill; 2001:619-669.

3. Hibbard BM, Jeffcoate TNA. Abruptio placentae. Obstet Gynecol. 1966;27:155-67.

4. Chamberlan GVP, Philipp E, Howlett B, Masters K. Br Birth Obstet Gynecol. 1970;45:160-3.

5. Green JR. Placenta abnormalities: Placenta previa and abruptio plcentae, Maternal fetal medicine. In: Creasy RK, Resnik R, eds. Principle and Practice. 3rd ed. Philadelphia, WB Saunders, 1989;588-602.

6. Crane JMG, Van Denhof MC, Dodds L, Armson A, Listen R. Neonatal outcomes with placenta previa. Obstet Gynecol. 1999;93:541-4.

7. Frederiksen MC, Glassenberg R, Stika CS. Placenta previa: A 22 year analysis. Am J Obstet Gynecol 1999;180:1432-6.

8. Ananth CV, Smulian JC, Vintziteos AM. Incidence of placental abruption in relation to cigarette smoking and hypertensive disorders during pregnancy: a meta-analysis of observational studies. Obstet Gynecol 1999;93:622-8.

9. Abdella TN, Sibai BM, Hays JM, Anderson GD. Relationship of hypertensive disease with abruptio placental. Obstet Gynecol. 1984;63:365-70.

10. Menon. Accidental haemorrhage. J Obst Gyne India. 1961;11:35-5.

11. Brenner WF, Edelman DA, Hendricks CH. Characteristics of patients with placenta previa and results of expectant management. Am J Obstet Gynecol. 1975;155:180-4.

12. William RF, William DF. Placenta previa: A critical appraisal of 8 years mangement. 1960;80:10-6.

13. Bhide A, Prefumo F, Maone J, Hollis B, Thilaganathan B. Placental edge to internal os distance in the late third trimester and mode of delivery in placenta previa. Br J Obstet Gynaecol. 2003;11:860-4.

14. Crane JMG, Vandenhof MC, Dodds L, Armson BA, Liston R. Maternal complications with placenta previa. Am J Perinatol. 2000;17:101-5.

15. B Lynch C, Coker A, Lawl AH, Abu I, Cowen MJ. The B-Lynch surgical technique for the control of massive postpartum hemorrhage: an alternative to hysterectomy? Five cases reported. $\mathrm{Br} \mathrm{J}$ Obstet Gynaecol. 1997;104:372-5.

16. O'Leary JA. Uterine artery ligation in the control of post caesarean haemorrhage. Reprod Med. 1990;46:189-93.

17. Clark SL, Phelan JP, Yeh SY, Bruce SR, Paul RH. Hypogastric artery ligation for obstetric haemorrhage. Obstet Gynecol. 1985;66:353-6.

18. Motwani MN, Sheth J, Narvekar NM, Purandene MC, Hansotia MD. Maternal mortality resulting 
from antepartum hemorrhage - Review of 20 years. J Obstet Gynecol India. 1989;39:364-6.

19. Dutt DC. Antepartum haemorrhage. In: Hiralal Konar, editor. Textbook of Obstetrics. 6th ed. New Central Book Agency, Calcutta; 2004:243-61.
Cite this article as: Jain S, Jain N, Dahiya P, Rohilla $\mathrm{S}$, Malik R. A prospective study of maternal outcome in antepartum haemorrhage in tertiary care center in northern India. Int J Reprod Contracept Obstet Gynecol 2016;5:29-34. 